\title{
PENGARUH FASHION CLOTHING INVOLVEMENT TERHADAP RECREATIONAL SHOPPER IDENTITY DENGAN GENDER SEBAGAI VARIABEL MODERASI
}

\author{
Yolla Margaretha \\ Henky Lisan S
}

\begin{abstract}
ABSTRAK
Penelitian ini lebih menekankan pada bagaimana pengaruh Fashion Clothing Involvement terhadap Recreational Shopper Identity dengan gender sebagai variabel moderasi. Metode analisis data yang digunakan untuk menguji keakuratan dan kekonsistenan instrumen penelitian adalah uji pendahuluan (validitas dan reliabilitas). Metode analisis data yang digunakan adalah analisis regresi dengan model mediasi serta menggunakan bantuan program SPSS 11.5 for Windows.

Berdasarkan hasil penelitian, maka kesimpulan akhir yang dapat ditarik adalah: Terdapat pengaruh Fashion Clothing Involvement terhadap Recreational Shopper Identity, sebesar adalah 9,6\%. Sedangkan sisanya 90,4\% dipengaruhi oleh faktor lain. Hasil penelitian ini mendukung teori yang mengatakan terdapat peranan Fashion Clothing Involvement dalam meningkatkan Recreational Shopper Identity dalam diri responden dan mendukung teori yang mengatakan bahwa terdapat perbedaan antara laki-laki dan wanita dalam hal Fashion Clothing Involvement dan Recreational Shopper Identity. Campbell (1997b) menjelaskan bahwa perempuan jauh lebih memiliki keterlibatan penuh dalam belanja dibanding laki-laki. Solomon (2004) menjelaskan bahwa pakaian merupakan bagian dari fashion adalah kategori produk yang dikenal dapat mencerminkan kehidupan sosial konsumen, fantasi, dan keanggotaannya.
\end{abstract}

Kata Kunci: Fashion Clothing Involvement, Recreational Shopper Identity, Gender

\section{PENDAHULUAN}

Direktur Riset Konsumer Nielsen, Catherine Eddy dalam Global Online Shopping Report oleh The Nielsen Company, menyatakan hasil survei bahwa Konsumen lakilaki Indonesia membeli buku (34 persen), perangkat keras komputer (33 persen) dan peralatan elektronik (32 persen). Sementara, konsumen wanita lebih memilih pakaian, aksesoris dan sepatu (43 persen) dan tiket penerbangan (37 persen) (www. detikfinance.com, 21 Mei 2011). Dari hasil survei dapat diambil kesimpulan bahwa kecenderungan orang Indonesia, terutama bergender wanita lebih sering untuk membeli pakaian sesuai mode/tren bukan sesuai dengan kebutuhan, hal ini menyebabkan permintaan yang terus-menerus selalu ada dan berganti sesuai musimnya. Walaupun sebenarnya orang tersebut sudah memiliki cukup banyak pakaian untuk digunakan, masih akan terus mencari dan membeli baju baru untuk mengikuti mode/tren dan perkembangan fashion. Bagi kaum perempuan, berbelanja adalah salah satu kegiatan yang menyenangkan dan bisa menghilangkan stres, atau dengan kata lain belanja adalah satu satu bentuk kegiatan refreshing. Dan jenis kelamin juga memberikan perbedaan dalam berbelanja. Perempuan memiliki afinitas pemikiran yang besar saat berbelanja, karenanya ia akan berjalan santai di setiap toko, memeriksa barang, membandingkan produk dan nilainya, berinteraksi dengan staf penjual, mengajukan pertanyaan, mencobanya hingga akhirnya melakukan pembelian. Apapun barang yang dipilih oleh seseorang baik saat membeli cokelat atau mobil sekalipun semuanya dipengaruhi oleh faktor genetik (Celsi, Rose, dan Leigh
1993). Oleh sebab itu perbedaan gender dalam penelitian dijadikan sebagai variabel moderasi.

Menurut beberapa ahli, pembelian produk fashion dapat dikatakan sebagai pembelian produk highinvolvement (O'Cass, 2001). Hal ini dikaitkan dengan waktu dan proses pengambilan keputusan untuk mengkonsumsi produk fashion yang biasa lama dan dipengaruhi berbagai hal yang kompleks. Pakaian yang merupakan bagian dari produk fashion adalah kategori produk yang dapat digunakan untuk mencerminkan kehidupan sosial konsumen, fantasi, dan keanggotaanya (Solomon, 1996). Perilaku konsumen dalam membeli produk fashion clothing sangat menarik untuk diteliti, karena hal itu sangat kompleks dan dilandasi oleh berbagai faktor.

Tentu saja banyak peluang bisnis lain yang bisa ditangkap sejalan dengan Fashion Clothing Involvement dan Recreational Shopper Identity. Apalagi sekarang banyak pusat perbelanjaan dan tempat rekreasi yang kini telah memiliki fungsi lain yaitu menjadi tempat mengekspresikan gaya hidup dan tempat meleburnya budaya. Fenomena ini akan terus berlanjut, karena diperkirakan pertumbuhan ekonomi di Indonesia akan terus meningkat, yang jumlah kelas menengah ke atas (middle-high) pun semakin bertambah. Berdasarkan berbagai uraian di atas, maka penelitian ini berjudul: " Pengaruh Fashion Clothing Involvement Terhadap Recreational Shopper Identity Dengan Gender Sebagai Variabel Moderasi. 


\section{KERANGKA PEMIKIRAN}

\section{Fashion Clothing Involvement}

Dalam Fashion Clothing konsumen memiliki keterlibatan penuh (High involvement) dalam perilakunya, keterlibatan tersebut dapat menjadi variabel yang mempengaruhi perilaku konsumen (Auty and Elliot, 1998; O'Cass, 2004). Fashion Involvement merupakan persepsi konsumen akan pentingnya fashion clothing (O'Class, 2001). Dan Fashion Clothing itu sendiri dapat diartikan hal-halyang berbeda untuk setiap konsumen yang berbeda-beda akan menciptakan item/ style pakaian yang berbeda juga. (Martin, 1998; O'Cass, 2000).

\section{Recreational Shopper Identity}

Jadi Recreational Shopping dapat didefinisikan sebagai kegiatan berbelanja yang dicirikan dengan perasaan senang dalam diri pelakunya (Guiry, Magi, Lutz, 2006). Perasaan senang ini muncul akibat dari proses berbelanja yang dilakukan, baik itu belanja barang maupun jasa. Sedangkan dimensinya dinamakan Recreational Shopper Indentity, yaitu dimensi konsep diri individu, dimana konsumen mendefinisikan dirinya sendiri dalam hal belanja untuk tujuan rekreasi maupun liburan.

Konsumen yang sangat terlibat dalam pakaian mode akan memiliki kecenderungan kuat untuk berinteraksi dengan bentuk fashion (O'Cass, 2004), dan fashion merupakan produk yang dikonsumsi publik, konsumen juga dapat melihat belanja sebagai kesempatan untuk mengamati tren fashion orang lain yang ada di pasar (Cox, Cox and Anderson, 2005). Campbell (1997a) menemukan bahwa belanja pakaian adalah fokus umum kegiatan belanja rekreasi. Dibandingkan dengan pembeli, para penggemar belanja rekreasi memiliki identitas kuat sebagai pembelanja rekreasi (Celsi, Rose and Leigh,1993). Hasil penelitian sebelumnya menunjukkan bahwa keterlibatan mode pakaian secara signifikan dipengaruhi oleh materialisme dan gender, dan pada gilirannya keterlibatan mode pakaian mempengaruhi identitas pembelanja rekreasi (Guiry, Magi, Lutz, 2006).

Demikian juga, Campbell menyatakan perbedaan gender berpengaruh kuat dalam berbelanja, dimana perempuan jauh lebih memiliki keterlibatan penuh dalam belanja dibanding laki-laki (Campbell, 1997a:167-168); Miller, Jackson, Holbrook, and Rowlands (1998: 144) menemukan bahwa pembeli perempuan mengembangkan rasa identitas melalui berbelanja. Sepaham dengan penelitian dari Campbell (1997b) yang menyatakan belanja adalah rekreasi dan penggemar belanja yang didominasi wanita. Namun, temuan ini memperluas penelitian sebelumnya dengan menunjukkan bahwa tidak hanya perempuan yang cenderung menikmati belanja lebih sebagai bentuk rekreasi tetapi juga bahwa belanja rekreasi dapat menjadi aspek pribadi mereka.

Gender juga telah ditemukan untuk mempengaruhi mode keterlibatan pakaian di konsumen (Auty and Elliot,
1998; O'Cass, 2004). Gender didefinisikan oleh Campbell (1997b) sebagai peran simbolik dikaitkan dengan anggota gender berdasarkan interpretasi historis yang dibangun dari disposisi, sifat dan peran anggota gender itu.", jadi Gender diidentifikasi sebagai variabel yang mempengaruhi kunci dalam mengidentifikasi perbedaan dalam lampiran konsumen untuk harta dan perilaku pasar yang menunjukkan keterlibatan konsumen (Auty and Elliot, 1998; Browne dan Kaldenberg, 1997; Dittmar, 1992; O'Cass, 2004).

Browne and Kaldenberg (1997) menemukan bahwa pembeli perempuan mengalami lebih besar keterlibatan dalam mode pakaian daripada pembeli laki-laki Hasil ini menunjukkan bahwa perempuan lebih tertarik pada atau lebih disesuaikan dengan mode dan lebih bersedia untuk mencoba gaya baru (Davis, 1994:27). Bagi konsumen yang sangat terlibat dalam pakaian fashion, karakteristik Recreational Shopper Identity mungkin lebih menonjol. Berdasarkan penjelasan di atas, maka penulis merumuskan hipotesis penelitian dan model penelitian sebagai berikut:

H1 : Tidak terdapat pengaruh moderasi gender terhadap Fashion Clothing Involvement dan Recreational Shopper Identity

H2 : Terdapat pengaruh moderasi gender terhadap Fashion Clothing Involvement dan Recreational Shopper Identity

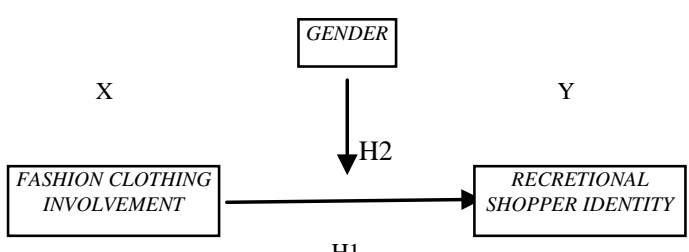

H1: X Tehadap Y

H2: Moderasi Terhadap $X$ dan $Y$

\section{Gambar Rerangka Model Dasar dan Path yang Dihipotesiskan}

\section{METODE PENELITIAN}

Jenis penelitian yang akan dilakukan dalam penelitian ini adalah predictive research. Predictive research yaitu penelitian yang mencoba menjelaskan apa yang akan terjadi dari suatu fenomena yang ada (Hartono, 2004). Dalam penelitian ini, peneliti mencoba untuk menjelaskan apa yang akan terjadi pada Recreational Shopper Identity berdasarkan Fashion Clothing Involvement dan Gender.

Metode pengambilan sampel dalam penelitian ini adalah convenience sampling. Convenience sampling adalah metode pengambilan sampel dengan mengambil sampel secara bebas sesuai dengan kehendak penelitinya (Hartono, 2004). 
4. HASIL PENELITIAN DAN PEMBAHASAN

Pengaruh Uji Fashion Clothing Involvementpada Recreational Shopper Identity

Hasil pengujian pengaruh Fashion Clothing Involvement terhadap Recreational Shopper Identity dapat dilihat dalam beberapa tabel berikut ini.

Tabel 1

Besar Pengaruh FCl pada RSI Model Summary ${ }^{\text {b }}$

\begin{tabular}{|l|r|r|r|r|}
\hline Model & R & R Square & $\begin{array}{c}\text { Adjusted } \\
\text { R Square }\end{array}$ & $\begin{array}{c}\text { Std. Error of } \\
\text { the Estimate }\end{array}$ \\
\hline 1 & $.309^{\mathrm{a}}$ & .096 & .086 & 3.86509 \\
\hline
\end{tabular}

a. Predictors: (Constant), FC

b. Dependent Variable: RS

Sumber: data yang diolah (2011)

Dari tabel di atas dapat dilihat bahwa besarnya pengaruh Fashion Clothing Involvement terhadap Recreational Shopper Identity adalah 9,6\%. Sedangkan sisanya 90,4\% dipengaruhi oleh faktor lain. Beberapa faktor lain yang mempengaruhi Recreational Shopper Identity antara lain interaksi dengan orang lain. Seperti yang telah dijelaskan pada kerangka pemikiran, bahwa Recreational Shopper Identity ini merupakan dimensi konsep diri yang melekat pada diri seseorang, dimana konsumen mendefinisikan dirinya sendiri dalam hal belanja untuk tujuan rekreasi maupun liburan (Guiry, Magi, Lutz, 2006).

Pengaruh interaksi dengan orang lain terhadap pembentukan konsep diri seperti ini dapat mungkin saja terjadi. Seperti yang dijelaskan oleh Prasetijo dan Ihalauw (2005), bahwa seseorang selalu mempunyai konsep diri yang dibentuk melalui interaksi dengan orang lain (baik itu dengan orang tuanya, teman, guru, dan lainnya dengan interaksi yang signifikan), jika seseorang berinteraksi secara intens dengan orang-orang yang memiliki Recreational Shopper Identity, maka ada kemungkinan besar orang tersebut akan memiliki konsep diri seperti itu juga. Selain interaksi dengan orang lain, Prasetijo dan Ihalauw (2005) juga mengatakan terdapat faktor lain yang dapat mempengaruhi konsep diri Recreational Shopper Identity ini, yaitu citra yang diinginkan seseorang di mata sendiri maupun orang lain mengenai dirinya. Mereka mengatakan bahwa penggunaan produk (sebagai hasil dari berbelanja) dapat dijadikan sebagai simbol mengkomunikasikan arti kepada dirinya sendiri dan kepada orang lain, sehingga berdampak pada konsep pribadi maupun konsep sosial seseorang. Apa yang dimiliki, dipercaya, akan mencerminkan konsep diri seseorang. Demikian halnya juga dengan Recreational Shopper Identity. Citra yang diinginkan akibat dari kegiatan berbelanja atau lebih spesifiknya berbelanja sebagai suatu rekreasi memiliki peranan besar dalam menciptakan konsep diri seperti ini.
Faktor lain, yang menurut peneliti merupakan faktor dasar yang dapat mempengaruhi orang untuk memiliki Recreational Shopper Identity adalah kepribadian. Allport merumuskan kepribadian sebagai "sesuatu" yang terdapat dalam diri individu yang membimbing dan memberi arah kepada seluruh tingkah laku individu yang bersangkutan (http://trescent. wordpress.com/2007/08/07/arti-dandefinisi-kepribadian/ 16 Maret 2011). Lebih detail tentang definisi kepribadian menurut Allport yaitu kepribadian adalah suatu organisasi yang dinamis dari sistem psikofisik individu yang menentukan tingkah laku dan pikiran individu secara khas. Allport menggunakan istilah sistem psikofisik dengan maksud menunjukkan bahwa jiwa dan raga manusia adalah suatu sistem yang terpadu dan tidak dapat dipisahkan satu sama lain, serta diantara keduanya selalu terjadi interaksi dalam mengarahkan tingkah laku. Dari pengertian mengenai kepribadian tersebut sangatlah jelas, jika kepribadian yang melekat dalam diri seseorang memiliki pengaruh yang sangat besar dalam pembentukan identitas orang tersebut, dan kemudian akan berdampak pada kegiatan apa yang dilakukan orang itu. Jika seseorang memiliki kepribadian yang terlalu mengutamakan kesenangan dalam hidup, ada kemungkinan dia memiliki konsep diri Recreational Shopper Identity.

Tabel 2. Uji Model Penelitian

\begin{tabular}{|c|c|c|c|c|c|c|}
\hline \multicolumn{7}{|c|}{ ANOVA $A^{b}$} \\
\hline Model & & $\begin{array}{c}\text { Sum of } \\
\text { Squares }\end{array}$ & $d f$ & Mean Square & $\mathrm{F}$ & Sig. \\
\hline 1 & Regression & 154.747 & 1 & 154.747 & 10.359 & $.002^{\mathrm{a}}$ \\
\hline & Residual & 1464.013 & 98 & 14.939 & & \\
\hline & Total & 1618.760 & 99 & & & \\
\hline
\end{tabular}

a. Predictors: (Constant), FC

b. Dependent Variable: RS

Sumber: data yang diolah (2011)

Dari tabel di atas dapat dilihat bahwa nilai signikansinya 0,02 atau kurang dari $<0,05$. Hal ini berarti bahwa model yang terdapat dalam penelitian ini dapat menggambarkan keadaan sesungguhnya mengenai pengaruh Fashion Clothing Involvement pada Recreational Shopper Identity. Ini berarti bahwa fenomena hubungan antara Fashion Clothing Involvement dan Recreation Shopper Identity dapat dijelaskan dengan baik dalam penelitian ini.

Tabel 3. Uji Pengaruh Fashion Clothing Involvement dan Recreation Shopper Identity

Coefficients

\begin{tabular}{|ll|r|r|c|c|c|}
\hline \multirow{2}{*}{ Model } & & \multicolumn{2}{|c|}{$\begin{array}{c}\text { Unstandardized } \\
\text { Coefficients }\end{array}$} & $\begin{array}{c}\text { Standardized } \\
\text { Coefficients }\end{array}$ & & \\
\cline { 2 - 5 } & & \multicolumn{1}{|c|}{ B } & Std. Error & Beta & \multicolumn{1}{c|}{ t } & \multicolumn{1}{c|}{ Sig. } \\
\hline 1 & (Constant) & 8.611 & 2.690 & & 3.201 & .002 \\
& FC & .464 & .144 & .309 & 3.218 & .002 \\
\hline
\end{tabular}

a. Dependent Variable: RS

sumner: aata yang aıoın ( 2 U I) 
Dari tabel di atas dapat dilihat bahwa nilai signifikansi untuk pengaruh Fashion Clothing Involvement pada Recreation Shopper Identity adalah 0,02 $(<0,05)$. Ini berarti terdapat pengaruh dari Fashion Clothing Invovement pada Recreation Shopper Identity. Hasil penelitian ini mendukung teori yang mengatakan terdapat peranan Fashion Clothing Invovement dalam meningkatkan Recreation Shopper Identity dalam diri responden. Solomon (2004) menjelaskan bahwa pakaian merupakan bagian dari fashion adalah kategori produk yang dikenal dapat mencerminkan kehidupan sosial konsumen, fantasi, dan keanggotaannya.

Demikian juga dengan Fischer, Eileen and Gainer, 1991) yang mengatakan bahwa motif pembelian konsumen bermacam-macam, ada yang dilandasi keinginan untuk trendy (be fasionable), ada yang ingin terlihat menarik (be attaractive), menimbulkan kesan di hadapan orang lain (impress other), dijadikan sebagai simbol penerimaan oleh kelompok sosial (be accepted by friends, peer gorup, colleagues), atau sebagai penyaluran kebutuhan psikologis (fill an emotional needs).

Ketiga pendapat di atas sepaham dengan pendapat Prasetijo dan Ihalauw (2005) di atas, yang mengatakan bahwa produk yang digunakan dapat mencerminkan status orang yang memakainya, dalam kasus ini adalah produk berupa pakaian.

\section{Uji Variabel Moderasi Gender}

Hasil uji variabel moderasi gender terhadap pengaruh Fashion Clothing Involvement terhadap Recreational Shopper Identity dapat dilihat dalam tabel-tabel di bawah ini.

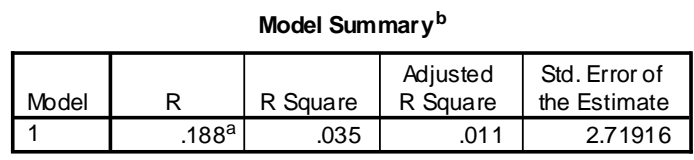

a. Predictors: (Constant), FC

b. Dependent Variable: RS

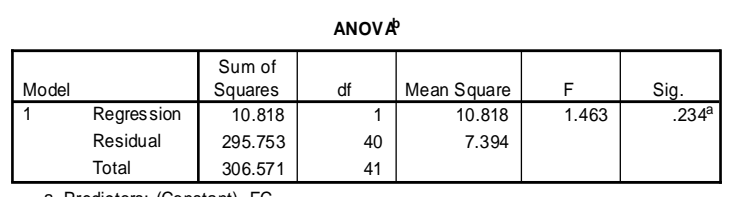

a. Predictors: (Constant), FC

b. Dependent Variable: RS

Tabel 4

Hasil Regresi Dengan Observasi Wanita

Sumber: data yang diolah (2011)

coefficients

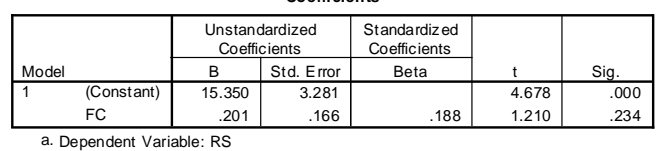

Sumber: data yang diolah (2011)

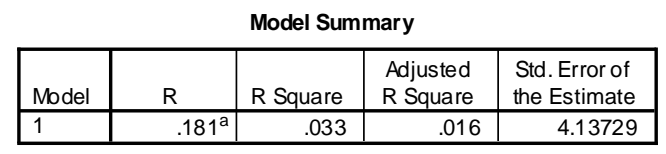

a. Predictors: (Constant), FC

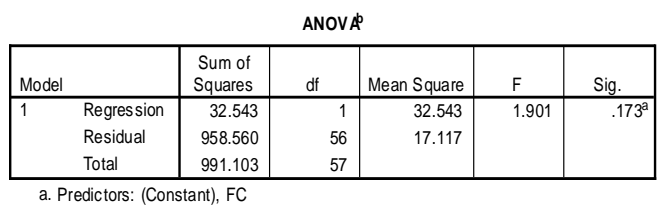

a. Predictors: (Constant), FC

b. Dependent Variable: RS

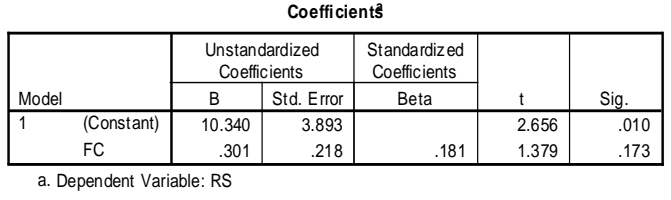

Tabel 5

Hasi Regresi Dengan Observasi Laki-laki

Sumber: data yang diolah (2011)

Untuk pengujian pengaruh moderasi, peneliti menggunakan Chow Test. Perhitungannya adalah sebagai berikut:

$$
\begin{aligned}
F & =\frac{(\text { RSSr }- \text { RSSur }) / k}{\text { RSSur } /(n 1+n 2-k)} \\
& =\frac{(1464,013-1251,313) / 2}{1251,313 /(41+57-2)} \\
& =\frac{106,35}{13,035} \\
& =8,16
\end{aligned}
$$

Dari perhitungan di atas, maka didapat $\mathrm{df}=2$ dan 96, serta $F$ hitung $=8,16$. Dengan tingkat signifikansi 0,05, melalui perhitungan secara online di alamat website (http://davidmlane.com/hyperstat/F table.html, 29 April 2011) dimana df numerator $=2$, df denumerator $=96$, dan $F=8,16$, didapat $p=0,00061$. Oleh karena $p$ value $<0,05$ ( $F$ hitung $>F$ tabel) dapat dikatakan bahwa model regresi dengan observasi antara laki-laki dan wanita menunjukkan perbedaan dengan kata lain pengaruh Fashion Clothing Involvement pada Recreational Shopper Identity antara laki-laki dan wanita berbeda.

Dari hasil tersebut maka berarti dalam penelitian ini terdapat pengaruh moderasi gender terhadap hubungan Fashion Clothing Involvement pada Recreational Shopper Identity. Hasil penelitian ini berarti mendukung teori yang mengatakan bahwa terdapat perbedaan antara laki-laki dan wanita dalam hal Fashion Clothing Involvement dan Recreational Shopper Identity. Campbell (1997b) 
menjelaskan bahwa perempuan jauh lebih memiliki keterlibatan penuh dalam belanja dibanding laki-laki.

Pendapat ini juga didukung oleh penelitian yang dilakukan Miller, Jackson, Holbrook, dan Rowlands (1998) yang menemukan bahwa perempuan pembeli lebih mengembangkan rasa identitas melalui berbelanja dibandingkan laki-laki.

\section{KESIMPULAN DAN SARAN}

Berdasarkan hasil penelitian, maka kesimpulan akhir yang dapat ditarik adalah: Terdapat pengaruh Fashion Clothing Involvement terhadap Recreational Shopper Identity, sebesar adalah 9,6\%. Sedangkan sisanya 90,4\% dipengaruhi oleh faktor lain. Hasil penelitian ini mendukung teori yang mengatakan terdapat peranan Fashion Clothing Involvement dalam meningkatkan Recreational Shopper Identity dalam diri responden dan mendukung teori yang mengatakan bahwa terdapat perbedaan antara laki-laki dan wanita dalam hal Fashion Clothing Involvement dan Recreational Shopper Identity. Campbell (1997b) menjelaskan bahwa perempuan jauh lebih memiliki keterlibatan penuh dalam belanja dibanding laki-laki. Solomon (2004) menjelaskan bahwa pakaian merupakan bagian dari fashion adalah kategori produk yang dikenal dapat mencerminkan kehidupan sosial konsumen, fantasi, dan keanggotaannya.

\section{DAFTAR PUSTAKA}

Auty, S., Elliott, R. (1998). Fashion involvement, selfmonitoring and the meaning of brands. Journal of Product and Brand Management 7 (2), 109123.

Browne, B., Kaldenberg, D. (1997). Conceptualizing selfmonitoring: Links to materialism and product involvement. Journal of Consumer Marketing 14 (1), 31-44.

Campbell, Colin. (1997a). "Recreational Shopping as the Context of Desire." In Sosiologisk Arbok, Vol. 2. Eds. Susann Solli, Arild bomassen, and Per Otnes. Oslo: Novus, 81-104.

Campbell, Colin. (1997b). "Shopping, Pleasure and the Sex War." In The Shopping Experience. Eds. Pasi Falk and Colin Campbell. London: Sage, 166-176.

Celsi, Richard L., Randall L. Rose, and Thomas W. Leigh. (1993). "An Exploration of High-Risk Leisure Consumption Through Skydiving. "Journal of Consumer Research 20 (June): 1-23.

Celsi L.R., Olson J.C. (1988). The role of involvement in attention and comprehension processes. Journal of Consumer Research 15, 210-224.

Cox, A. D., Cox, D., Anderson, R.D. (2005). Reassessing the pleasures of store shopping. Journal of Business Research 58, 250-259. Science. Volume 34, No. 1, pages 74-83.
Davis, F., 1994. Fashion, culture and identity, University of Chicago Press, Chicago.

Dittmar, H., 1992. The Social Psychology of Material Possessions: To Have is to be, Harvester Wheatsheaf, Hemel Hempstead.

Fischer, Eileen and Brenda Gainer. 1991. "I Shop Therefore I Am: The Role of Shopping in the Social Construction of Women's Identities."In Proceedings of the Conference on Gender and Consumer Behavior,Vol. i. Salt Lake City, UT: Association for Consumer Research, 350-357.

Guiry, Magi dan Lutz, R.J. (2006). Defining and Measuring Recreational Shopper Identity. Journal of the Academy of Marketing Science. Volume 34, No. 1, pages 74-83.

Hartono, J. (2004). Metodologi Penelitian Bisnis: Salah Kaprah dan Pengalaman-pengalaman. Edisi 2004/2005. Cetakan pertama. Yogyakarta: BPFE.

Martin, C., (1998). Relationship marketing: A highinvolvement product attribute approach. Journal of Product and Brand Management 7 (1), 6-26. Ohio.

Miller, Daniel, Peter Jackson, Beverly Holbrook, and Michael Rowlands. (1998). Shopping, Place and Identity. London: Routledge.

O'Cass, A. (2000). An assessment of consumers' product, purchase decision, advertising and consumption involvement in fashion clothing. Journal of Economic Psychology 21 (5), 545-576.

O'Cass, A. (2001). Consumer self-monitoring, materialism and involvement in fashion clothing. Australian Marketing Journal 9 (1), 46-60.

O'Cass, A. (2004). Fashion clothing consumption: antecedents and consequences of fashion clothing involvement. European Journal of Marketing 388 (7), 69-82.

Prasetijo, R. dan Ihalauw, J. (2005). Perilaku Konsumen. Edisi I. Penerbit Andi Yogyakarta.

Solomon, Michael R. (1996). Consumer Behavior: Buying, Having, and Being. Upper Saddle River, NJ: Prentice Hall.

Solomon, M.R., Rabolt, N.J. (2004). Consumer Behavior in Fashion, Prentice-Hall, Englewood Cliffs, New Jersy.

uww. detikfinance.com, 21 Mei 2011

http://demografi.bps.go.id, 2 Februari 2011.

http://trescent.wordpress.com/2007/08/07/arti-dan-definisikepribadian/, 16 Maret 2011

http://davidmlane.com/hyperstat/F_table.html,

Commuri dan Jun (2003:3), 29 April 2011. 